Fournal of Medical Genetics (1971). 8, 188.

\title{
A Family with Balanced Translocation, $\mathrm{t}(5 \mathrm{p}-; \mathrm{Gp}+)$
}

\author{
BEVERLY J. WHITE, LISA C. VAN DE WATER, and JOE-HIN TJIO \\ From the Laboratory of Experimental Pathology, National Institute of Arthritis and Metabolic Diseases, Bethesda, \\ Maryland, USA
}

There are many reports of families with balanced reciprocal translocations between B group chromosomes and autosomes of other groups, including D chromosomes (Wolf et al, 1966; de Capoa et al, 1967; Mennicken et al, 1968), G chromosomes (Gustavson et al, 1964; de Grouchy and Gabilan, 1965), and a number 3 chromosome (Mennicken et al, 1968). These families were ascertained because of a propositus with an unbalanced karyotype. In some cases where the translocation involved the short arm of the B chromosome, balanced translocation heterozygosis resulted in offspring with either deletion (cri-du-chat syndrome) or duplication of the short arm of the B chromosome. Two reported B;G translocations (Gustavson et al, 1964; de Grouchy and Gabilan, 1965) are similar to the family described here. A B;G carrier and her family ascertained fortuitously will be described in this report.

\section{Case Reports}

Case II.4. The proposita, a Caucasian female (II.4, Fig. 1), was first seen at the NIH Clinical Center at age 22 years for evaluation of an abnormal karyotype discovered during another study (Tjio, Pahnke, and Kurland, 1969). She was the product of her mother's third normal full-term pregnancy; her mother was 20 and her father 24 years old at the time of her birth. Infancy was normal, but behaviour problems became apparent at school age, manifested by a poor academic record, truancy, difficulty in controlling aggressive impulses, and conflict with parents. Menarche at 11 years of age was normal, but laparotomy was done at 12 years because of lower abdominal pain associated with dysfunctional uterine bleeding of 3 months' duration. A large appendix surrounded by adhesions and a Meckel's diverticulum were excised; 'multiple follicular-type cysts' were seen on the surfaces of both 'large' ovaries. The uterus and fallopian tubes were structurally normal, and histological sections of the appendix and diverticulum were unremarkable. A dilatation and curettage done at the same time revealed normal endometrium. Later, she received intermittent iron therapy and antibiotics from

Received 28 August 1970. her physicians for continued dysfunctional uterine bleeding and chronic pelvic inflammatory disease associated with anaemia. At age 20 years, she was briefly hospitalized because of a post-partum depressive reaction and suicide attempt. There was no evidence of psychosis, and she responded well to psychotherapy. At age 22 years, height was $164 \mathrm{~cm}$ and weight $59 \mathrm{~kg}$. Physical examination was negative except for the presence of pelvic adhesions and tenderness, compatible with her history of chronic pelvic inflammatory disease. Routine laboratory tests were negative. The Wechsler verbal scale IQ was 87, performance scale IQ 95, and full scale IQ 90. The Wechsler memory scale score was 95 , and no cognitive defects were noted with the Bender Gestalt Test.

Case III.1. The first pregnancy of the proposita was normal, with delivery at term of a $2977 \mathrm{~g}$ normal male. Growth and development of this child was unremarkable, although he was seen by a neurologist at age 5 years because of hyperactivity. 'Short attention span' and 'immaturity with fine motor sequencing tasks' were noted, but no other neurological abnormalities were present. When first examined at the NIH Clinical Center at age 5 years, 2 months, height was $113 \mathrm{~cm}$, weight $20.3 \mathrm{~kg}$, and occipitofrontal circumference (OFC) $53 \mathrm{~cm}$. No dysmorphic features were present, but bruxism, short attention span, and mild hyperactivity were evident. Routine laboratory studies were negative. At age 5 years, 5 months, performance on the Wechsler Preschool and Primary Scale of Intelligence gave him a verbal scale IQ of 109, performance scale IQ of 89, and full scale IQ of 99. Language expression was normal, but he had difficulty with other expressive forms such as maze tracing and drawing simple geometric designs. He was enrolled in special education classes at the time of the examination.

Case III.2. The second pregnancy of the proposita was terminated at 38 weeks because of bleeding secondary to placenta praevia, and a $2778 \mathrm{~g}$ male was delivered by Caesarean section. Apgar score was 6 at 5 minutes after delivery, and transient repiratory distress developed during the first day of life. Blood phenylalanine level was normal ( $2 \mathrm{mg} \%$ ) at 4 days of age. He was a lethargic infant who fed slowly, and early development was also 'slow'. At age 19 months developmental level estimated by a neurologist was 13 months. Repeat evaluation at age 24 months indicated overall function was consistent with chronological age. At age 4 years, 


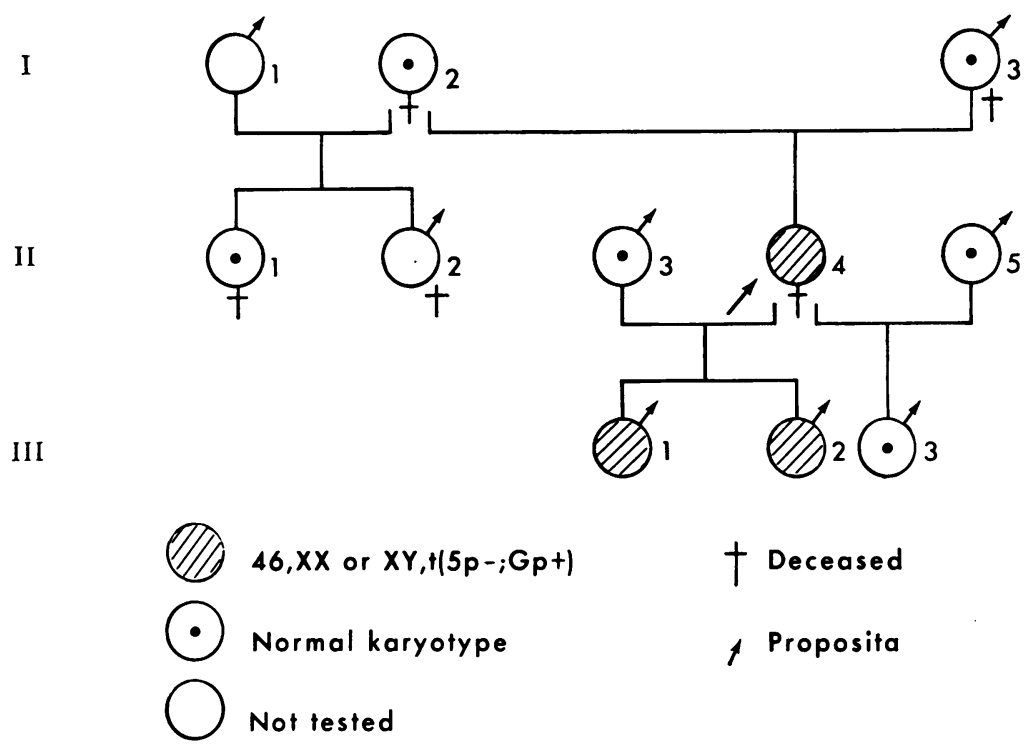

FIG. 1. Family pedigree.

6 months, examination at the NIH Clinical Center revealed an alert male, height $103 \mathrm{~cm}$, weight $15.9 \mathrm{~kg}$, and OFC $51 \mathrm{~cm}$. Neurological examination was negative, but severe dental caries and pectus excavatum were present. Routine laboratory tests were negative. At age 4 years, 7 months, the Merrill-Palmer Scale of Mental Tests and Wechsler gave an overall IQ of 109. No deficits in perceptual or expressive skills were evident, and geometric design subtest performance was normal.

Case III.3. The third child (III.3) was the product of a 'full term' pregnancy complicated by failure to seek medical care, urinary tract infection, and spontaneous rupture of membranes $\mathbf{4 8}$ hours before delivery. Birth weight of the male infant was $2410 \mathrm{~g}$. His subsequent course was unremarkable and developmental landmarks were normal. At the NIH Clinical Center examination at age 2 years, 6 months was negative; weight was $13.5 \mathrm{~kg}$, height $94.5 \mathrm{~cm}$, and OFC $51 \mathrm{~cm}$. A mild microcytic, hypochromic anaemia was present and was related to a history of dietary iron deficiency. On the Merrill-Palmer Scale of Mental Tests given at age 2 years 10 months he achieved an IQ score of 91.

Other members of the family. The mother (I.2) of the proposita gave a history of 'ovarian cysts' and dysfunctional bleeding, resulting in hysterectomy in her mid-20s. The father (I.3) of the proposita had malaria at age 18 years treated with atabrine and quinine and died recently at age 46 years following a myocardial infarction. The half-brother (II.2) of the proposita was 'slow in school but not retarded' and died in an accident at age 18 years. The father (II.3) of the two oldest boys (III.1 and 2), and the father (II.5) of the youngest boy (III.3) were phenotypically normal. None of the family members reported any abortions, stillbirths, infant deaths, or congenital defects.

\section{Methods}

Chromosome studies were done using 72-hour peripheral blood cultures. Details of the culture and harvesting techniques have been described in a previous report (Tjio, et al, 1969). For autoradiographic studies, ${ }^{3} \mathrm{H}$-thymidine (final concentration 0.5 to $1.0 \mu \mathrm{c} / \mathrm{ml}$ ) was

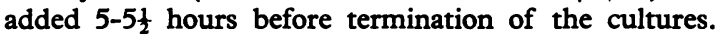
Colcemide, $0 \cdot 1 \mu \mathrm{g} / \mathrm{ml}$ was added 2 hours before termination. Metaphases stained with orcein were photographed, and the slides were dipped in Kodak NTB-2 emulsion. Exposure to the emulsion varied from 2 to 3 days, and the slides were developed in Kodak D-19 developer. Cells with suitable grains were then rephotographed.

Finger and palm prints were obtained using the Faurot inkless method, and heparinized blood samples were drawn from family members for blood grouping, serum protein typing, and erythrocyte enzyme studies.

\section{Results}

The results of chromosome analysis of family members are summarized in Table I. In all cases, cells with less than 46 chromosomes were due to random loss of chromosomes from different groups. With the exception of the proposita and 2 of her 3 sons, all members had normal karyotypes. The proposita had a chromosome number of 46 , and only 3 apparently normal $B$ and $G$ chromosomes were present. A large acrocentric with a long arm 
TABLE I

SUMMARY OF CYTOGENETIC STUDIES

\begin{tabular}{|c|c|c|c|c|c|c|}
\hline \multirow{2}{*}{$\begin{array}{c}\text { Generation } \\
\text { and } \\
\text { Member }\end{array}$} & \multicolumn{4}{|c|}{$\begin{array}{c}\text { Chromosome } \\
\text { Counts }\end{array}$} & \multirow{2}{*}{$\begin{array}{l}\text { Total } \\
\text { Cells }\end{array}$} & \multirow[t]{2}{*}{ Karyotype* } \\
\hline & 44 & $45 t$ & 46 & 47 & & \\
\hline $\begin{array}{l}\text { I.2 } \\
\text { I. } 3 \\
\text { II.1 } \\
\text { II. } 3 \\
\text { II. } 4 \\
\text { III.5 } \\
\text { IIII.1 } \\
\text { III.2 } \\
\text { III } .3\end{array}$ & $\begin{array}{l}\mathbf{0} \\
1 \\
0 \\
0 \\
0 \\
0 \\
0 \\
0 \\
0\end{array}$ & $\begin{array}{l}2 \\
2 \\
1 \\
1 \\
1 \\
2 \\
4 \\
0 \\
2\end{array}$ & $\begin{array}{r}98 \\
97 \\
65 \\
99 \\
99 \\
116 \\
98 \\
123 \\
85 \\
59\end{array}$ & $\begin{array}{l}\mathbf{0} \\
0 \\
0 \\
0 \\
0 \\
0 \\
0 \\
0 \\
0\end{array}$ & $\begin{array}{r}100 \\
100 \\
66 \\
100 \\
117 \\
100 \\
127 \\
85 \\
61\end{array}$ & $\begin{array}{l}\text { 46,XX } \\
46, X Y \\
46, X X \\
46, X Y \\
46, X X, t(5 p-; G p+) \\
46, X Y \\
46, X Y, t(5 p-; G p+) \\
46, X Y, t(5 p-; G p+) \\
46, X Y\end{array}$ \\
\hline
\end{tabular}

* Chicago Conference (1966).

t All due to random loss.

equal in length to the long arm of a normal B chromosome and a small metacentric comparable in size to the No. 16 chromosomes were present in all of the cells. One arm of the small metacentric had a prominent constriction near the centromere; it was presumed to be the short arm of a B chromosome involved in a reciprocal translocation with the short arm of a $\mathrm{G}$ chromosome. The other arm of the small metacentric resembled the long arm of a $G$ chromosome in length. Her karyotype, 46,XX, $t(5 p-; G p+)$, is shown in Figure 2. This same apparently balanced translocation was present in all of the cells studied of her two oldest sons (III.1 and 2 ), whose karyotypes were $46, X Y, t(5 p-; G p+)$. The karyotype of her youngest son (III.3) was normal.

Autoradiographic studies of the proposita and her three children are presented in Figure 3. The typical B group replication pattern of one latereplicating pair (No. 4), and one pair replicating early along most of the long arm and late along the short arm (No. 5) (German, 1967) was found in the normal child (III.3). One normal late-labelling No. 4 pair was present in all three of the carriers, and their third normal B chromosome demonstrated the early-replicating pattern of No. 5 . Frequently the short arm of the normal No. 5 was prominently late-labelling. Replication of the large acrocentric translocation chromosome was early and typical of the long arm of No. 5. In many heavily-labelled cells the small metacentric translocation chromosome was early-replicating along one arm and prominently late-labelling along the arm with the constriction presumed to be the translocated short arm of No. 5.

Results of the dermatoglyphic studies are listed in Table II. The axial triradius was in position $t^{\prime}$ in both hands of two of the carriers. It was in position $t$ on the right and position $t^{\prime}$ on the left hand of carrier III.1. In the normal sib, the position was $t$ bilaterally. The father (II.3), who was not available for palm printing, and oldest son (III.1) resembled each other in having ulnar loops on all 10 fingers. The father (II.5) of the youngest boy was not available for dermatoglyphic analysis. None of the individuals examined had simian creases.

There were no unusual findings in the blood group phenotyping, or erythrocyte enzyme and serum protein typing, and the patterns of inheritance were consistent with the pedigree obtained. This information is presented in Table III.

\section{Discussion}

Gustavson et al (1964) described the family of a phenotypically normal woman carrying the balanced translocation, $t(B p-; G p+)$. She was studied after delivering an infant with multiple anomalies who was trisomic for the short arm of the involved B chromosome. These authors suggest that four types of gametes would be produced during meiosis of balanced $B ; G$ carriers. The resulting zygotes, assuming a normal gamete was contributed by the other parent, would include: 1 trisomy for the short arm of the B chromosome: 1 monosomy for the short arm of the $B: 1$ balanced $B ; G$ carrier: 1 normal. In the second case, it is possible that a balanced carrier could have a viable infant with the cri-du-chat syndrome if the chromosome involved was No. 5. Absence of the short arm is apparently compatible with life, since the 'entire' (McCracken and Gordon, 1965) or 'major portion' (Macintyre et al, 1964) of the short arm has been reported to be absent in de novo cases of cri-du-chat syndrome.

De Grouchy and Gabilan (1965) reported another family with a B;G translocation. The proband, with features of cri-du-chat syndrome, had a normal karyotype except for deletion of part of the short arm of a presumed No. 5 chromosome. The phenotypically normal mother carried a balanced translocation between the entire short arm of a $B$ chromosome and the short arm of a $\mathrm{G}[46, \mathrm{XX}$, $\mathrm{t}(\mathrm{Bp}-; \mathrm{Gp}+)]$. Of interest was a proposal to explain only partial deletion of a B short arm in the child, when the mother carried a translocation involving the entire short arm. These authors suggested a rearrangement of the mother's B and G chromosomes more complex than appearance of her karyotype would suggest. As a consequence of this unique rearrangement, a B chromosome with partial deletion of the short arm could result from crossing over during neiosis of the balanced carrier. However, a simple deletion of one of the carrier's other normal B chromosomes or one of the father's normal B chromosomes during gameto- 


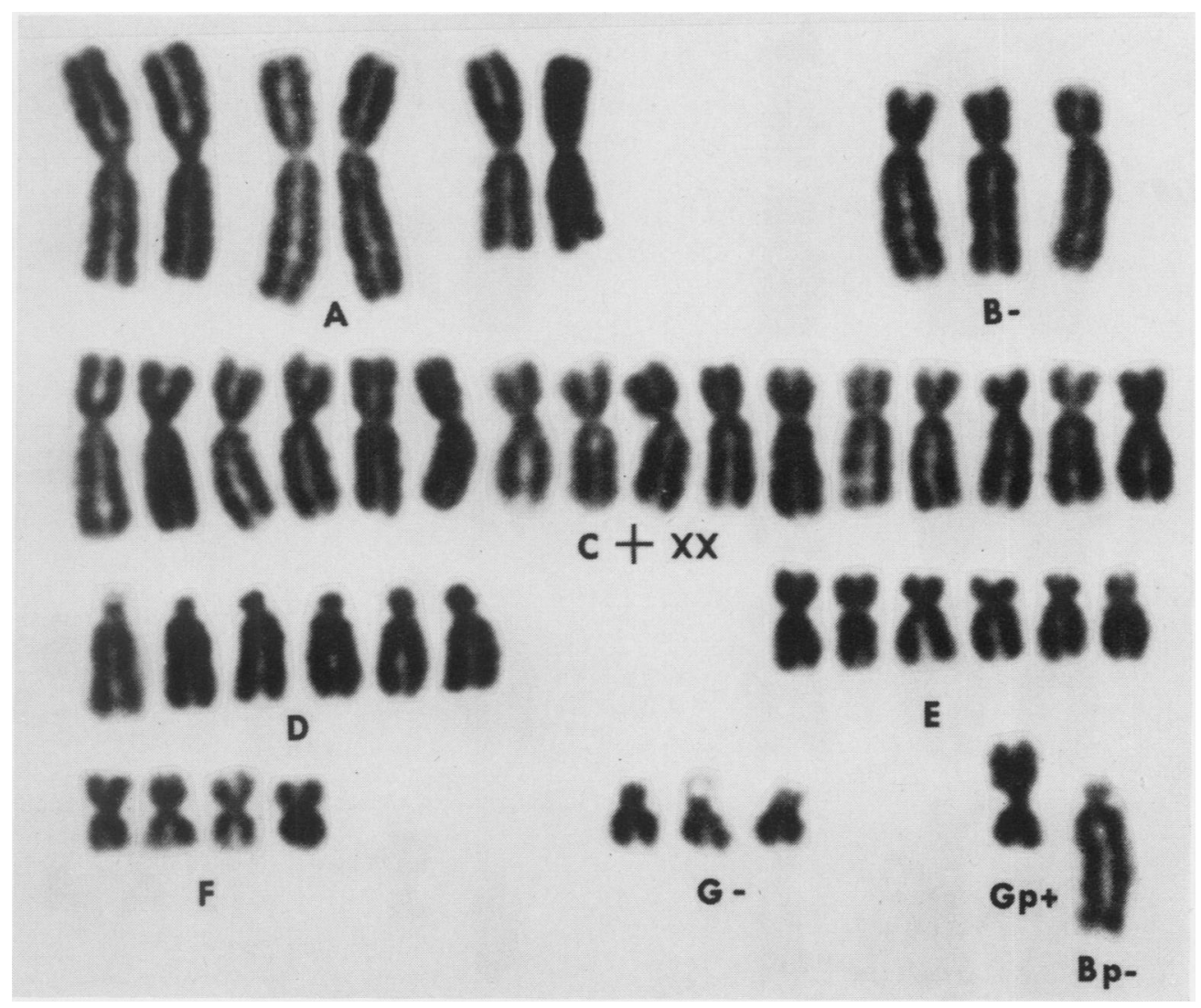

FIG. 2. Karyotype of proposita showing the $B ; G$ translocation.

genesis, with transmission of the deletion to the child, would also be possible. From the evidence presented it is difficult to confirm the application of this proposal, which was first termed 'aneusomie de recombinaison' by Lejeune and Berger (1965). Genetic risk is difficult to predict in terms of their theory, since it would be dependent upon the incidence and number of crossovers occurring in the regions involved in the translocation.

Ford and Clegg (1969) note that cytological evidence in man indicates formation of a ring quadrivalent during first meiotic metaphase of reciprocal translocation carriers. A quadrivalent could disjoin to produce balanced (alternate segregation) or unbalanced (adjacent- 1 or adjacent- 2 segregation) gametes. They suggest that the frequency of various gamete types is unique for each translocation case. Thus, factors such as changes in relative position of centromeres produced by the rearrangement, as well as number and 'distribution' of cross- overs would determine the mode of disjunction. There were more heterozygotes than normals among the offspring of 561 human translocation heterozygote matings reviewed by Ford and Clegg (1969), and the incidence of spontaneous abortions was not greatly increased $(21.7 \%)$ over that estimated for the general population (15\%). There were no spontaneous abortions in the B; $G$ family presented here, and the tendency to produce heterozygous offspring may indicate a preference for alternate segregation. However, the $B ; G$ carriers reported by Gustavson et al (1964) and de Grouchy and Gabilan (1965) demonstrate that there is a significant chance of unbalanced segregation in such cases. If simple segregation occurs in $B$; $G$ carriers in the fashion suggested by Gustavson et al (1964), a balanced carrier would have a $50 \%$ risk of producing zygotes with unbalanced karyotypes.

A review of other reported cases of B group translocations provides interesting results. De 


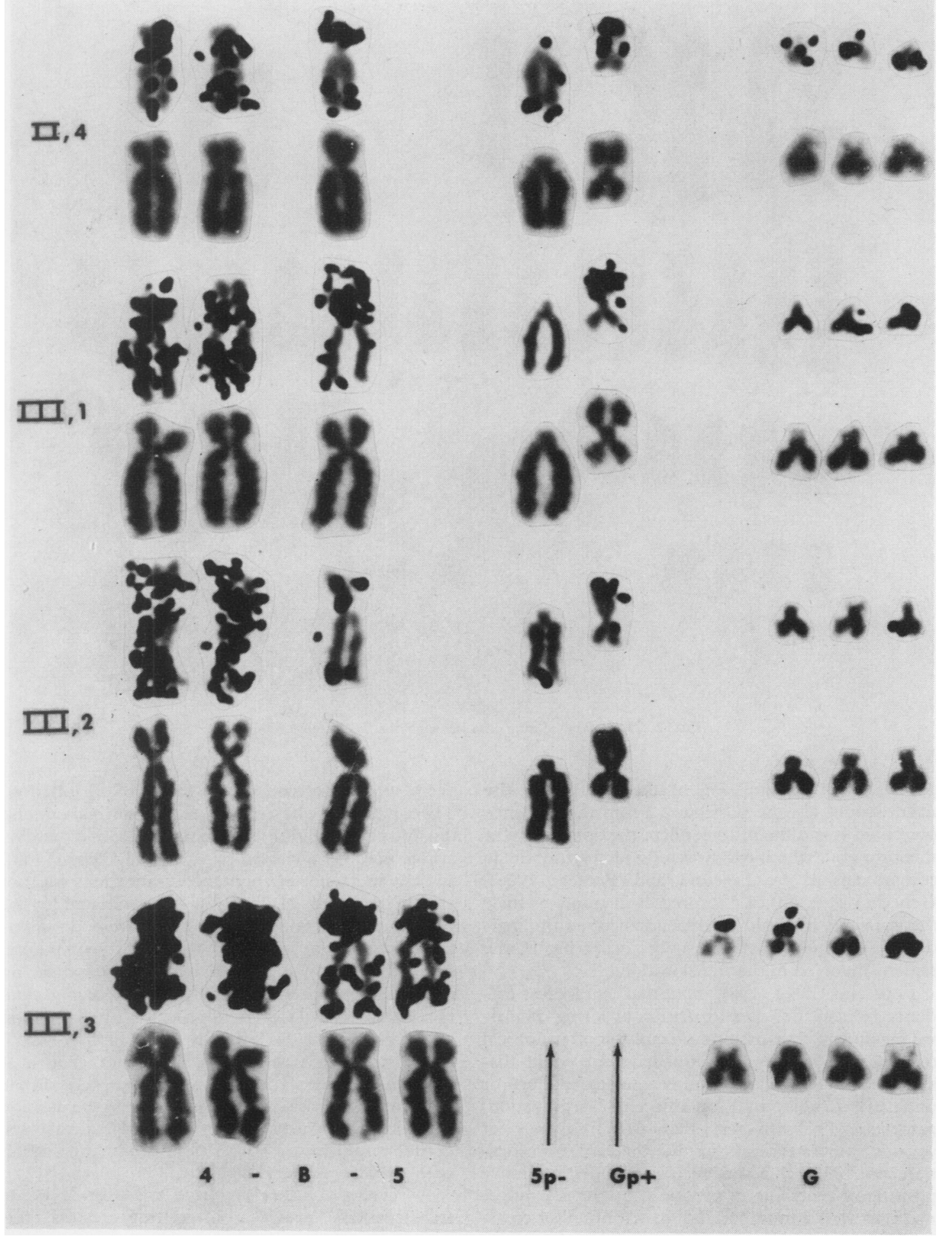

FIG. 3. Autoradiographs of the $\mathrm{B}, \mathrm{G}$, and $\mathrm{t}(5 \mathrm{p}-; \mathrm{Gp}+)$ chromosomes of the proposita and her sons showing the labelling patterns. 
TABLE II

DERMATOGLYPHS OF FAMILY MEMBERS

\begin{tabular}{|c|c|c|c|c|c|c|c|}
\hline \multirow{2}{*}{\multicolumn{2}{|c|}{$\begin{array}{c}\text { Generation } \\
\text { and } \\
\text { Member }\end{array}$}} & \multicolumn{5}{|c|}{ Digits } & \multirow{3}{*}{ Palmar Patterns } \\
\hline & & \multirow{2}{*}{$\frac{\mathbf{I}}{\mathbf{L}_{\mathbf{L}^{\mathbf{u}}}^{\mathbf{u}}}$} & \multirow{2}{*}{ 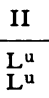 } & \multirow{2}{*}{ 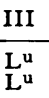 } & \multirow{2}{*}{ 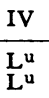 } & \multirow{2}{*}{$\frac{\mathrm{V}}{\mathbf{L}_{\mathbf{L}}^{\mathbf{u}}}$} & \\
\hline II. 3 & $\begin{array}{l}\text { Right } \\
\text { Left }\end{array}$ & & & & & & \\
\hline II.4 & $\begin{array}{l}\text { Right } \\
\text { Left }\end{array}$ & W & $\underset{W}{\mathbf{W}}$ & $\begin{array}{l}\mathbf{L}^{\mathbf{u}} \\
\mathbf{L}^{\mathbf{u}}\end{array}$ & $\begin{array}{l}\text { W } \\
\mathbf{L}^{u}\end{array}$ & $\mathrm{~L}^{\mathrm{u}} \mathrm{L}^{\mathrm{u}}$ & $\begin{array}{l}10 \cdot \mathrm{X} \cdot{ }^{6} \cdot 5^{\prime}-t^{\prime}-\mathrm{L}^{\mathrm{r}} / \mathrm{A}^{\mathrm{c}} \cdot \mathrm{O} \cdot \mathrm{M} \cdot \mathrm{O} \cdot \mathrm{M} \\
9 \cdot 7^{\prime} \cdot 5^{\prime \prime} \cdot 5^{\prime}-t^{\prime}-\mathrm{A}^{\mathrm{u}} / \mathrm{A}^{\mathrm{c}} \cdot \mathrm{M} \cdot \mathrm{M} \cdot \mathrm{O} \cdot \mathrm{L}^{\mathrm{d}}\end{array}$ \\
\hline III.1 & $\begin{array}{l}\text { Right } \\
\text { Left }\end{array}$ & $\mathbf{L}^{\mathbf{u}}$ & $\begin{array}{l}L^{u} \\
L^{u}\end{array}$ & $\begin{array}{l}\mathbf{L}^{\mathbf{u}} \\
\mathbf{L}^{\mathbf{u}}\end{array}$ & $\mathbf{L}^{\mathbf{u}}$ & $\begin{array}{l}\mathbf{L}^{\mathbf{u}} \\
\mathbf{L}^{\mathbf{u}}\end{array}$ & $\begin{array}{l}11 \cdot 9 \cdot 7 \cdot 5^{\prime}-t-A^{u} \cdot O \cdot M \\
10 \cdot X \cdot 5^{\prime} \cdot 5^{d} \cdot t^{\prime}-L^{r} / A^{c} \cdot V \cdot M\end{array}$ \\
\hline III. 2 & $\begin{array}{l}\text { Right } \\
\text { Left }\end{array}$ & $\underset{\mathrm{D}}{\mathbf{W}}$ & $\underset{L^{u}}{\mathbf{W}}$ & $\begin{array}{l}\mathbf{L} \mathbf{u} \\
\mathbf{L}^{\mathbf{u}}\end{array}$ & $\underset{\mathbb{W}}{\mathbb{W}}$ & $\underset{\mathbf{L}}{\mathbf{W}}$ & $\begin{array}{l}11 \cdot{ }^{9} \cdot 7^{7} \cdot 5^{\prime}-t^{\prime}-A^{u} \cdot V \\
9 \cdot 7^{\prime \prime} \cdot 5^{\prime}-t^{\prime}-A^{u} / A^{c} \cdot V / L^{r} \cdot M^{O} \cdot L^{d} \cdot L^{M}\end{array}$ \\
\hline III. 3 & $\begin{array}{l}\text { Right } \\
\text { Left }\end{array}$ & $\begin{array}{l}\mathbf{W} \\
\mathbf{L}^{\mathbf{u}}\end{array}$ & $\begin{array}{l}L^{r} \\
L^{u}\end{array}$ & $\underset{\mathbf{W}}{\mathbf{W}}$ & $\underset{\mathbb{W}}{\mathbf{W}}$ & $\begin{array}{l}\mathbf{L}^{\mathbf{u}} \\
\mathbf{L}^{\mathbf{u}}\end{array}$ & $t$ \\
\hline
\end{tabular}

$\mathrm{W}=$ whorl; $\mathrm{D}=$ loop double; $\mathrm{L}^{\mathrm{u}}=$ loop ulnar; $\mathrm{L}^{\mathrm{r}}=$ loop radial; $\mathrm{L}^{\mathrm{d}}=$ loop distal; $\mathrm{A}^{\mathrm{u}}=\operatorname{arch} \mathrm{ulnar} ; \mathrm{A}^{\mathrm{c}}=$ arch carpal; $M=$ fan or multiplication; $O=$ no pattern; $V=$ vestige.

TABLE III

RESULTS OF RED BLOOD CELL PHENOTYPING, SERUM PROTEIN TYPING, AND ERYTHROCYTE ENZYME STUDIES

\begin{tabular}{|c|c|c|c|c|c|c|c|c|}
\hline \multirow{2}{*}{ System Tested } & \multicolumn{8}{|c|}{ Generation and Member } \\
\hline & I. 2 & I.3 & II. 3 & II.4 & II. 5 & III.1 & III. 2 & III.3 \\
\hline 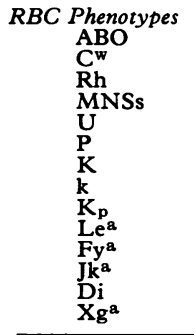 & $\begin{array}{l}\text { B } \\
\text { DCce } \\
\text { Ns } \\
+ \\
+(w k) \\
- \\
+ \\
a-b+ \\
+ \\
+ \\
+ \\
a-* \\
+\end{array}$ & $\begin{array}{l}\mathrm{A}_{1} \\
\overline{\mathrm{DC}} \mathrm{CEe} \\
\text { MNSs } \\
+ \\
+ \\
\overline{+} \\
+ \\
\mathrm{a}-\mathrm{b}+ \\
+ \\
\overline{+} \\
\mathrm{a}-\mathrm{b}+ \\
+\end{array}$ & $\begin{array}{l}\mathrm{A}_{1} \\
- \\
\mathrm{D} c \mathrm{Ee} \\
\text { NSs } \\
+ \\
+ \\
+ \\
+ \\
\mathrm{a}-\mathrm{b}+ \\
+ \\
+ \\
\mathrm{a}-\mathrm{b}+ \\
+\end{array}$ & $\begin{array}{l}\text { B } \\
- \\
\text { DCce } \\
\text { MNSs } \\
+ \\
+ \\
+ \\
+ \\
a-b+ \\
+ \\
+ \\
+ \\
a-* \\
+\end{array}$ & $\begin{array}{l}\text { O } \\
\bar{D} c E e \\
\text { MNSs } \\
+ \\
+ \\
+ \\
+ \\
a-b+ \\
+ \\
= \\
a-b+ \\
+\end{array}$ & $\begin{array}{l}\text { O } \\
\text { DCcEe } \\
\text { NSs } \\
+ \\
+ \\
+ \\
+ \\
a-b+ \\
+ \\
+ \\
\frac{+}{a-b+} \\
+\end{array}$ & $\begin{array}{l}A_{1} \\
\bar{D} \text { Cce } \\
\text { Ns } \\
+ \\
- \\
\overline{+} \\
+ \\
a-b+ \\
+ \\
+ \\
a-b+ \\
+\end{array}$ & $\begin{array}{l}\text { B } \\
\overline{D C c E e} \\
\text { MNs } \\
+ \\
+(\mathbf{s}) \\
+ \\
+ \\
\mathrm{a}-\mathrm{b}+ \\
+ \\
+ \\
\mathrm{a}- \\
+\end{array}$ \\
\hline $\begin{array}{c}\text { RBC Enzymes } \\
\text { PGM } \\
\text { AP } \\
\text { AK }\end{array}$ & $\begin{array}{l}1-1 \\
B \\
1-1\end{array}$ & $\begin{array}{l}1-1 \\
\text { BA } \\
1-1\end{array}$ & $\begin{array}{l}1-1 \\
B \\
1-1\end{array}$ & $\begin{array}{l}1-1 \\
B \\
1-1\end{array}$ & $\begin{array}{l}2-1 \\
\text { BA } \\
1-1\end{array}$ & $\begin{array}{l}1-1 \\
B \\
1-1\end{array}$ & $\begin{array}{l}1-1 \\
B \\
1-1\end{array}$ & $\begin{array}{l}2-1 \\
\text { BA } \\
1-1\end{array}$ \\
\hline $\begin{array}{c}\text { Serum Proteins } \\
\text { Hp } \\
\text { Alb } \\
\text { Gc } \\
\text { Tf }\end{array}$ & $\begin{array}{l}2-1 \\
N \\
2-1 \\
C\end{array}$ & $\begin{array}{l}2-1 \\
N \\
2-1 \\
C\end{array}$ & $\begin{array}{l}2-1 \\
N \\
2-1\end{array}$ & $\begin{array}{l}2-1 \\
\text { N } \\
2-1 \\
C\end{array}$ & $\begin{array}{l}2-1 \\
\mathrm{~N} \\
\mathrm{C}\end{array}$ & $\begin{array}{l}2-1 \\
N \\
2-1 \\
C\end{array}$ & $\begin{array}{l}2-1 \\
\text { N } \\
\text { C }\end{array}$ & $\begin{array}{l}2-1 \\
\text { N } \\
\text { C }\end{array}$ \\
\hline
\end{tabular}

$*=$ Not tested for $\mathrm{Di}^{\mathrm{b}}$.

$\mathbf{P G M}=$ phosphoglucomutase; $\mathbf{A P}=$ acid phosphatase; $\mathrm{AK}=$ adenylate kinase; $\mathbf{H p}=$ haptoglobin; $\mathbf{A l b}=$ albumin $;$ $\mathrm{N}=$ normal albumin pattern; $\mathrm{Gc}=$ group specific component; $\mathbf{T} \mathbf{f}=$ transferrin; $(\mathrm{wk})=$ weakly positive; (s) =strongly positive.

Capoa et al (1967), studied three such families detected because balanced carriers produced infants with cri-du-chat syndrome. In one family part of the short arm of a B chromosome was involved in a translocation with a $\mathrm{D}$ chromosome; in the other two cases part of a B short arm was involved in a translocation with an unidentified chromosome. Two children in the B;D family were apparently trisomic for part of the short arm of a No. 5 chromosome; they were without significant 5-J.M.G. congenital anomalies but were mentally retarded. Autoradiography indicated the specific B chromosome was No. 5 in these cases. Their proposal for segregation during meiosis of carriers is consistent with that of Gustavson et al (1964). They noted an equal frequency of male and female translocation carrier parents in their study and estimate, from combining their cases with other cri-du-chat cases already in the literature, that $13 \%$ are associated with translocations. They concluded that 'simple 
translocation' is more common than the type of complex rearrangement suggested by de Grouchy and Gabilan (1965).

Identification of chromosomes No. 4 and 5 by means of their distinctive replication patterns is consistent in the literature and is reviewed by German (1967). Warburton et al (1967) in labelling studies of deleted-B cases observed the typical pattern was not altered by deletion. Chromosome No. 5 appears to be involved in the family described here, and the pattern of the translocated short arm of chromosome No. 5 was apparently not altered by its change in position within the karyotype. In certain rodents (Bianchi and de Bianchi, 1969) rearrangements can alter the replication pattern, but there is no evidence for this in our cases.

Unusual dermatoglyphic features have not been found in carriers of translocations involving the $B$ group. One B;G carrier reported (de Grouchy and Gabilan, 1965) had a single axial triradius in position $t^{\prime}$; this was a characteristic of the carriers reported here, but its significance is difficult to interpret because $t^{\prime}$ is present in $17 \%$ (Uchida, 1967) to $22 \%$ (Cummins and Midlo, 1961) of individuals from certain normal populations. The presence of 10 ulnar loops in one of the male carriers and his normal father, also seen in 4 to $7 \%$ of a normal control population studied by Uchida (1967), was present in 25 to $30 \%$ of individuals with Down's syndrome studied by her.

Unusual patterns of inheritance of blood group phenotypes, erythrocyte enzymes, and serum protein types were not found in this family. This finding was also typical of other families with altered B chromosomes reported.

\section{Summary}

The family of an individual with an uncommon reciprocal translocation, $t(5 p-; G p+)$ was studied. The balanced translocation was transmitted from the proposita to 2 of her 3 sons. The karyotypes of the other family members, including her third son, were normal. All were phenotypically normal although one of the sons carrying the translocation had a learning disorder. No unusual findings were present in dermatoglyphic or blood grouping studies. A review of cases similar to this family in- dicated that such balanced carriers are a significant source of offspring with duplication or deficiency (cri-du-chat) syndromes.

The authors are grateful to Dr. Kenneth Brown, Mr. Webster Leyshon, Mr. Leonard Taylor, and Mr. Robert Johnson of the Human Genetics Branch, National Institute of Dental Research, NIH, for performing the blood cell and protein studies and to Dr. Gordon Allen, Laboratory of Socioenvironmental Studies, National Institute of Mental Health, NIH, for assistance with the dermatoglyphic studies.

\section{REFERENCES}

Bianchi, N. O. and de Bianchi, M. S. A. (1969). Origin of the pattern and chronology of chromosome replication in vertebrates. Genetics, Suppl., 61, 275-287.

Chicago Conference: Standardization in Human Cytogenetics (1966). Birth Defects: Original Article Series II, 2. The National Foundation-March of Dimes, New York.

Cummins, H. and Midlo, C. (1961). Finger Prints, Palms and Soles. Dover, New York.

De Capoa, A., Warburton, D., Breg, W. R., Miller, D. A., and Miller, O. J. (1967). Translocation heterozygosis: A cause of five cases of cri du chat syndrome and two cases with a duplication of chromosome number five in three families. American fournal of Human Genetics, 19, 586-603.

Ford, C. E. and Clegg, H. M. (1969). Reciprocal translocations. British Medical Bulletin, 25, 110-114.

German, J. (1967). Autoradiographic studies of human chromosomes. I. A review. In Proceedings of the Third International Congress of Human Genetics, ed. J. F. Crow and J. V. Neel. Johns Hopkins, Baltimore.

Grouchy, J. de, and Gabilan, J. C. (1965). Translocation $5 \sim 21-22$ et syndrome du cri du chat. Annales de génétique, 8, 31-38.

Gustavson, K.-H., Finley, S. C., Finley, W. H., and Jalling, B. (1964). A 4-5/21-22 chromosomal translocation associated with multiple congenital anomalies. Acta paediatrica, 53, 172-181.

Lejeune, J. and Berger, R. (1965). Sur deux observations familiales de translocations complexes. Annales de génétique, 8, 21-30.

Macintyre, M. N., Staples, W. I., LaPolla, J., and Hempel, J. M. (1964). The 'cat cry' syndrome. American fournal of Diseases of Children, 108, 538-542.

McCracken, J. S. and Gordon, R. R. (1965). 'Cri du chat' syndrome. A new clinical and cytogenetic entity. Lancet, 1, 23-25.

Mennicken, U., Pfeiffer, R. A., Puyn, U., Worbes, H., and Wagener, A. (1968). Klinische und cytogenetische Befunde von 7 Patienten mit Cri-du-chat-Syndrom. Zeitschrift für Kinderheilkunde, 104, 230-256.

Tjio, J. H., Pahnke, W. N., and Kurland, A. A. (1969). LSD and chromosomes. A controlled experiment. Fournal of the American Medical Association, 210, 849-856.

Uchida, I. A. (1967). Role of dermatoglyphics in clinical cytogenetics. In Proceedings of the Third International Congress of Human Genetics, ed. J. F. Crow and J. V. Neel. Johns Hopkins, Baltimore.

Warburton, D., Miller, D. A., Miller, O. J., Breg, W. R., De Capoa, A., and Shaw, M. W. (1967). Distinction between chromosome 4 and chromosome 5 by replication pattern and length of long and short arms. American fournal of Human Genetics, 19, 399-415.

Wolf, U., Reinwein, H., Gey, W., and Klose, J. (1966). Cri-duchat-Syndrom mit Translokation $5 / D_{2}$. Humangenetik, 2, 63-77. 